\author{
Miron Wolny \\ University of Warmia and Mazury in Olsztyn \\ miron.w@wp.pl \\ ORCID 0000-0001-7835-128X \\ https://doi.org/10.26881/gsp.2019.3.08
}

\title{
LEX CLAUDIA DE NAVE SENATORUM - POSSIBILITIES OF NEW INTERPRETATIONS ${ }^{1}$
}

The lex Claudia presented in the work of Livy was a prohibition which in its essence limited the earning capacity of senators. Livy places it in the broader context of his statement: "Of the consuls designate, Flaminius, to whom the legions wintering at Placentia had been assigned by lot, dispatched an edict and a letter to the consul, commanding that these troops should be ready in the camp at Ariminum on the Ides of March. It was here, in his province, that he designed to enter on the consulship, for he remembered his former controversies with the senators, which he had waged when a tribune of the plebs, and later as consul - in the first place about his consulship, which they tried to annul, and again concerning his triumph. He was also hated by the senators on account of an unprecedented law which Quintus Claudius the tribune of the plebs had introduced, despite the opposition of the senate, with the backing of Gaius Flaminius alone of all that body, providing that no senator or senator's son should own a sea-going ship of more than three hundred amphoras burden - this was reckoned to be sufficient to transport the crops from one's fields, and all money-making was held unseemly in a senator. The measure, which was vehemently opposed, had been productive of great resentment on the part of the nobles against Flaminius, who had advocated its enactment; but had procured for him the favour of the plebs and afterwards a second consulship." 2

Modern research on this legal provision attempts to perform a multi-aspect analysis of the prohibition, especially in the context of available knowledge of economic relations in Rome in the third century BC (cf. Hill, 1952, passim; Shatz-

\footnotetext{
1 Completion of this text was possible thanks to the author's stay at the Library of Universität Bremen in May 2018.

2 Livy, Per. 21.63.1-4 (transl. B.O. Foster).
} 
man, 1975, passim; Baltrusch, 1989, 33-35), in order to underscore its importance in terms of limiting maritime trade conducted by senators. Most works devoted to this issue are only perfunctorily concerned with the methodology of research on the legal provisions of the republican period (including lex Claudia), or dispense with this kind of reflection altogether. As a result, lex Claudia is analyzed and interpreted in the context of systemic legal solutions adopted by the Roman state (cf. Grziwotz, 1985, passim; Kunkel, 1995, 612), or in the context of the propaganda exposure of the less significant arguments used in political struggles. Both of these broadly outlined directions should obviously not be questioned, but one should be aware of the limitations arising from excessively simple analogization of political and social relations in Rome in the third century BC and in the first century BC, given that the majority of literary sources, available in a wide representation contributed to the existence of permanent change in the perception of the earlier history of Rome (see in details: Kienast, 1973, passim; Develin, 1985, passim; Momigliano, 1986). Obviously, if Roman legislation also served political purposes, there is no doubt that the Lex Claudia quoted by Livy is a good example of that. Therefore, it is not possible to separate the interpretation of the lex Claudia law from the activity of Gaius Flaminius, and especially to ignore the controversy over his political activity. In turn, these issues are rooted in the course of the Second Punic War, which now cannot be considered without the adoption of a critical methodology in the study of literary sources, which may lead to the redefinition of particular elements of military, political and social history, and therefore Roman legislation as well. The brief text translated here, based on an examination of previous studies on lex Claudia, aims above all at identifying elements on which further research on the law can rely, thus indicating the theoretical possibilities of a new interpretation of lex Claudia de nave senatorum that derives from the findings of previous research.

The lex Claudia was originally described only in Livy's piece of work that discussed the law in the context of the Second Punic War and C. Flaminius's activities, one of the most contentious politicians of the Roman times ( $c f$. Lippold, 1963, 150; Brizzi, 1984; Oebel, 1993, 9-11). While presenting the events at the end of 218 BC, Livy emphasizes that Flaminius was elected consul for the next year and that he was assigned to take responsibility over the legions, then quartering near Placentia. The elected consul sent a letter to Tiberius Sempronius Longus, the consul in office, with a command to have the army in encamped at Ariminum by the beginning of the official year (the Ides of March) since it was there that C. Flaminius decided to take the office. ${ }^{3}$ Livy explains the rationale behind the unusual decision taken by Flaminius (the consul refused to enter the office in Rome) in a broader digression. He believed that C. Flaminius took such a decision due to a long-standing conflict with the Senate. As Livy explains, this contention started

\footnotetext{
3 Livy, Per. 21.63.1: Consulum designatorum alter Flaminius, qui eae legiones, quae Placentiae hibernabant,
} sorte evenerant, edictum ad litteras ad consulem misit, ut is exercitus idibus Martiis Arimini adesset in castris. 
when C. Flaminius was holding the tribunate and lasted throughout Flaminius's first consulship. At that time, attempts were initially made to deprive Flaminius of his office and later he was denied the right to the triumph. ${ }^{4}$

By way of an aside, Livy discusses the lex Claudia, claiming that C. Flaminius fell into the senate's disfavor when Quintus Claudius, the tribune of the plebs, pursued a new act contesting the senatorial class. Alone among the senators, C. Flaminius is believed to have supported the tribune. This law reduced the tonnage of senators' ships to 300 amphorae, which was sufficient to maintain agricultural operations yet prevented the senators from participating in trade activities. The law substantiated that the trade was unworthy of senators. According to Livy, the issue sparked violent hatred of the nobles towards Flaminius while winning him the esteem of the plebs and finally leading Flaminius to a victory in the rivalry for the consulate. Livy himself emphasizes that the law was not in fact that dangerous for the landholders of the state grounds as they were not involved in trade operations.

The fact that the lex Claudia is discussed in a specific part of Livy's work seems to shed a positive light on the historicity of this account (cf. Händl-Sagawe, 1995, 396). Even considering the lack of possibility of attesting the information regarding the law with a justified direct parallel (excluding suggestions) in any other work, the description presented by Livy specifies the limit of the vessel tonnage and outlines how the law was first deliberated and finally included in the Roman legislative procedures. All of this prompts a wider discussion on the law and its relationships with Caius Flaminius's political activities.

In the context of preliminary considerations, the moment of introducing the law seems quite significant. The correct interpretation of the law depends to a certain extent on the chronology which, in this case, is subject to controversy. Most researchers accept the chronology of Livy and date lex Claudia to 218 BC (cf. Jenny, 1936, 3; Meyer, 1975, 96; Lippold, 1963, 93; Bleicken, 1968, 31; El Beheiri, 2001, 57). The option of 219 BC, argued mainly by Z. Yavetz, constitutes a separate position in research dictated by an entire scientific theory of research. These chronological discrepancies have material consequences. If the law had been adopted in 219 $\mathrm{BC}, 5$ its political goals could have been radically different than in $218 \mathrm{BC}$, i.e. during the Second Punic War.

For Z. Yavetz, the outbreak of the Second Punic War was conducive to the aggravation of political antagonisms, but it did not change the fact that Flaminius remained politically isolated: "After the outbreak of the Second Punic War, rela-

\footnotetext{
${ }^{4}$ Livy, Per. 21.63.2: hic in provincia consulatum inire consilium erat memori veterum certaminum cum patribus, quae tribunus plebis et quae postea consul prius de consulatu, qui abrogabatur, dein de triumpho habuerat.

5 Yavetz (1962), 325, explains that lex Claudia was passed in 219 BC, because from 287 BC Plebiscita were considered as leges therefore the term lex Claudia appears frequently. Owing to fact that presumably date of Claudius' tribunship was in 219 BC See: Broughton (1953), 238; Gundel (1979). Arguments for year 220 BC see: Willems (1878), 202.
} 
tions between Flaminius and the Fabii became strained even more, but Flaminius was not supported by Aemilii Scipiones in the Plebiscitium Claudianum, for it explicitly said that Flaminius remained isolated in the senate: uno patrum adiuvante C. Flaminio" (cf. Yavetz, 1962, 327). According to Yavetz, Flaminius' actions are coupled with political antagonism ( $c f$. also Bleicken, 1968, 40-41; Scullard, 1973, 53-55). Still, T. Frank contends that Flaminius' actions, reflected in the legislation, made him a defender of the senatorial dignity and traditional lifestyle (Frank, $2004,64)$, which in the period of the Second Punic War would systematically decline, ultimately reaching the catastrophic dimensions known from the work by Sallustius (cf. Büchner, 1960, passim; Bonamente, 1975; Astin, 1978, 91-95; Conley, 1981). On the other hand, F. De Martino pointed to Flaminius' stubbornness in his consistent efforts to curb the lawlessness of the senate, which was also manifested in the systematic attempts to free the republican regime from religious restrictions that in fact benefited the oligarchy (De Martino, 1964, 126). F. Cassola perceived Flaminius as a unifier of the rural plebs against the municipal plebs (Cassola, 1962, 227-228), while J. Seibert believed that electing Flaminius as tribune played the role of a catalyst in the senatorial policy (Seibert, 1993, 88). However, A. Pelletier indicated a certain statutory pragmatism associated with the outbreak of the Second Punic War and drew attention to the possibility of a statutory security for heavy ships that might have been needed in the face of the war with Carthage (Pelletier, 1969). These theories suggest an element of a broader plan, which would have essentially intended to strengthen the internal situation in Italy, in Flaminius's activities to champion Lex Claudia. Lex Claudia de nave senatorum, according to the theory posited by J.C. Domínguez Pérez, was to contribute to the limitation of commercial activities and the inflow of foreign goods, mainly Greek ones, and thus to encourage the revival of native production in Italy (Domínguez Pérez, 2005). R. Develin, despite certain idealization of Flaminius, denies him participation in a deliberate, broader scheme, bringing the circumstances to the foreground: "We cannot attribute to Flaminius any grandiose game plan, we cannot fit him into a factional niche and we cannot build a popular movement around him (...). Flaminius was above all an individual and a talented one of proven integrity, a man willing to stand up for his beliefs and oppose restrictive convention when it obstructed the interest of the state, in short, a man prepared to follow his own counsel, whatever the consequences." ${ }^{\prime 6}$

Therefore, several theoretical possibilities were considered in modern science which could have resulted in the proceedings concerning the specific lex Claudia provision. New research postulations were formulated, referring even more to the attempts to raise awareness of the research restrictions resulting from the optic adopted in the late Republic, especially the perception inherent in Cicero's works, as pointed out by N. El Beheiri (2001). However, M. Wolny tried to link

${ }^{6}$ Develin (1979), 277, 273: "But we are trying too hard to fit Flaminius into a pattern, to impose supposition of total consistency, making no allowance for the influence of contingent circumstances?" 
Flaminius' advocacy of lex Claudia with the previous stages of his political career and to identify another element that may have contributed to of Flaminius's rising popularity and prestige as a Roman politician in the legal domain (Wolny, 2007). Perhaps it is worth looking at the theory and practice of the functioning of the law and try to find any pertinent references or allusions, though not in the late Republic, but in the contemporary literary sources of the Second Punic War.

The phrase written by Livy (ne quis senator cuive senator pater fuisset maritimam naves) implies that the law applied to all senators, without exceptions, and their sons were prohibited from owning maritimam navem with a displacement exceeding 300 amphorae (approximately 8 tonnes). As rightly assumed by $\mathrm{H}$. Wildt, the term maritime naves means sea-going vessels exclusively (Wildt, 1994, 178). The text of the act warrants the conclusion that maritime naves were restricted in terms of carrying capacity. Furthermore, Wildt aptly states that from an objective point of view it was relatively easy for the agents involved in trade, to get around those rules - the clients could take the place of the senators. Admittedly, it was Th. Mommsen $(1976,854)$ who claimed that the wording questus omnis points to different legal implications of this law, whereby it aimedat preventing the senators from leasing the ships. However Z. Yavetz $(1962,341)$ took a more reserved standpoint observing that that was not necessarily true.

It was believed that vessels with a carrying capacity of 300 amphorae were sufficient to ship crops, yet the average agricultural production level was the starting point as the specific volume of freight had been set. Consequently, one was allowed to operate a higher number of smaller ships on a wider scale; however, was it cost-effective? Answering this question may reveal the rationale behind the backlash on the part of the senators.

Undoubtedly, in C. Flaminius's times, the senators were not supposed to receive financial benefits from many kinds of activities, but to treat trade as unworthy of their profession instead, as suggested by Livy, and rule by decency. Agricultural activities were thought to be the best and the fairest form of financial investment, which is reflected both in Cato and Cicero. Nevertheless, perusal of the texts of these authors demonstrates that the trade was not all neglected (cf. El Beheiri, 2001, 58). For Cato, trade was merely hazardous while Cicero differentiated between small-scale and large-scale trade. This offers evidence that at some earlier point in time in the Roman juridical history, appropriate legal regulations on trade activities conducted by senators must have come into existence. As assumed by H. Wildt $(1994,178)$, it is possible that since the Lex Claudia, there was an ongoing process that influenced Cato and Cicero, which would render justice to the normative impact of the actual state of affairs.

Ironically, this seems to be corroborated by the information found in Maccius Plautus's comedy entitled Mercator, which mentions a ship with 300 metretes, 
meaning a carrying capacity of more than 300 amphorae. ${ }^{7}$ As calculated by H. Hill, the metrete equaled 8-9 gallons given that one Roman amphora would be $2 / 3$ of the former's volume. The ship mentioned by Plautus could have had a displacement of 8.5 tonnes, which justifies the contemptuous expression to describe it, name ludicrously small (cf. Hill, 1958). It may be noted that the passus comes from a theatre play whose author set it in the Greek environment to place the sensitive issue of earning money from trade in a different reality. He presented the issue in the Greek realities (hence the metrete), but it was readily understandable for his audience since the reference to recent law was very clear.

In view of the scarcity of sources, especially legal sources concerning the history of Rome in the third century BC, as well as significant limitations of the Roman literary tradition of the first century BC and later, it seems an absolute necessity to go beyond the work of Plautus, which was a kind of response to the current problems of the Roman society. Plautus used a variety of methods to entertain the viewer. However, to achieve this effect he most often used either ready-made patterns, ${ }^{8}$ or resorted to the situational humour that Romans understood. In relation to Plautus' work, it is also interesting that there is no clear allusion to the activity of Gaius Flaminius. It is all the more intriguing that, considering the scale of negative assessments of this politician - also due to his involvement in the lex Claudia - one should expect a greater resonance of these events in the Roman custom, which should have reflected in the literature of that period. Undoubtedly, this leads to the conclusion that negative overtones in Flaminius's portrayal result from the qualities he was attributed posthumously and derive directly from the consul's defeat in the Battle of Lake Trasimene (dies ater). In line with the Greek literary tradition, C. Flaminius's defeat was understood as punishment for haughtiness. According to Polybius, the consul's haughtiness owed to excessive trust in his own strength whilst being unaware of political and military incompetence, quickness, audacity, brashness, covetousness, vaingloriousness, and conceit. ${ }^{9}$ The posthumous appraisal of C. Flaminius tallied with political contestation that lent it harsher and more radical features, as if indicating a political conflict. However, Livy unarguably approaches this dispute from the standpoint of the turbulent historical events of the late Republic, namely the bloody political strife that was so typical of the Gracchean times.

In science, this state of affairs has been known for a long time, and attempts have been made to demonstrate that the conflict between Flaminius and Quintus

\footnotetext{
7 Plaut. Merc. 73-79: Postquam recesset vita patrio corpore, / agrum se vendidisse atque ea pecunia / navem, metretas quae trecentas tolleret, I parasse atque ea se mercis vectatum undique, I adeo dum, quae tum haberet, peperisset bona / me idem decree, si ut decerem me forem, in translation: "After life had left his father's body, he had sold the farm and with money bought a ship of fifteen ton burden and marketed his cargoes of merchandise everywhere, till he had at length acquired the wealth which he then passed. I ought to do the same, if I where what I ought to be" [trans. Nixon (1924), 80].

8 Fron an example of this method, see: Krahmalkov (1988).

9 Polyb. 2.33.7-8; 3.80.3-4, 81.9-10, 82.3, 83.7, 84.6.
} 
Fabius Maximus was exaggerated. What is more, attempts have also been made to suggest that, in fact, these politicians worked closely together, as R. Develin emphasizes: "Servilius, consular colleague of Flaminius in 217, is seen as an opponent; hence it is argued that the same votes which elected Flaminius consul also made Fabius' dictator on Flaminius' death. None of these arguments is very strong, though we are to feel their cumulative effect. Still, the cumulation of weak units does not make for overall strength." Further, Develin argues: "Fabius had in fact a part in the application of the lex Flaminia after Flaminius' death" and "The strongest evidence for their association is the possibility that Flaminius was magister equitum under Fabius as dictator in 221" (Develin, 1979, 269-270).

The excessive exposure of Flaminius' denunciations in the narratives of the late Republic may result from an antithetic juxtaposition which is well-known in literature: Flaminius appears in this scheme as a popular politician, a demagogue, a self-righteous and unmanageable man opposed by the conservative Fabius, a stable politician who does not act under the influence of emotions and is guided by reason. Decoding this "scheme of contradictions" between Flaminius and Fabius does not necessarily preclude the conjecture of a hidden friendship or cooperation between the seemingly quarrelling politicians. In fact, at the time of Flaminius' activity, crowned by the enactment of the lex Claudia, Fabius may have been neutral towards him. It was only the death of the consul at the Battle of Lake Trasimene that is likely to have changed the perception of this figure, as it may have contributed to the spread of his opinions concerning Flaminius' strategic skills. In this case, the deceased politician had no counter-argument at all.

C. Flaminius's political activity, manifesting in the support for the Lex Claudia, may have stemmed from his broader political programme. An inquiry into the nature of Flaminius's advocacy of other laws, such as Lex Flaminia de agro Gallico et Piceno or Lex Metilia could offer insights into that programme, and yield more conclusions. The perception of C. Flaminius has undoubtedly changed, not only in Roman historiography but also in modern research (as scholars disentangle family and corporate relationships and their impact on Roman politics, a mode of inquiry pursued by T.R.S. Broughton or, in particular, Z. Yavetz). Having been ascertained, the fact that a relationship existed between Flaminius and the circle of the Aemilii and their patrons reveals a feature of his political activity. Other features include innovativeness and competitiveness of the political programme, in which the need to democratize the republican system - which came to the fore in the period of the Gracchi reforms - had its roots (cf. Earl, 1963, passim).

The dispute surrounding Flaminius was triggered by the devastating defeat he had suffered, which ultimately must have led to the dissatisfaction of the critics - who became his political opponents - of all Flaminius' undertakings, including the promotion of the lex Claudia. For this reason, the phrase invisus etiam patribus erat ob novam legem is an unquestionable part of the literary convention and does not reflect the actual assessment of this legal provision. Despite the ex- 
tensive scientific debate to date, further research on the discussed law still offers much in terms of potential findings. Leaving aside the rather perplexing issue of the system of mutual protection of high-ranking Roman officials, consideration the economic situation of Italy at the beginning of the Second Punic War opens up a possibility for new interpretations in further scientific inquiry on the law. This constitutes a challenge requiring new comprehensive research, also including sources that are less often taken into account (mainly Plautus' work).

\section{Secondary Sources}

Astin, A. (1978), Cato the Censor, Oxford.

Baltrusch, E. (1989), Regimen morum, die Reglementierung des Privatlebens der Senatoren und Ritter in der römischen Republik und frühen Kaiserzeit, München.

Bleicken, J. (1968), Das Volkstribunat der klassischen Republik, München.

Bonamente, G. (1975), Il metus punicus e la decadenza di Roma in Sallustio, Agostino ed Orosio, GIF 7, pp. 137-169.

Brizzi, G. (1984), Riflesioni sulla morte di un console, [in:] idem (ed.), Studi di storia annibalica, Faenza, pp. 33-43.

Broughton, T.R.S. (1953), The Magistrates of the Roman Republic, vol. 1, New York.

Büchner, K. (1960), Sallust, Heidelberg.

Cassola, F. (1962), I gruppi politici romani nel III secolo a. C., Trieste.

Conley, D.F. (1981), The Stages of Rome's Decline in Sallust's Historical Theory, Hermes 109, pp. 379-382.

De Martino, F. (1964), Storia della constituzione romana, vol. 1, Napoli.

Develin, R. (1979), The Political Position of C. Flaminius, RhM 122, pp. 268-277.

Develin, R. (1985), The Practice of Politics at Rome 366-167 B.C., Brüssel.

Domínguez Pérez, J.C. (2005), La Lex Claudia de nave senatorum a la luz de la epigrafia latina sobre ánforas greco-itálicas arcaicas, Polis. Revista de ideas y formas politicas de la Antiguedad Clásica 17, pp. 73-96.

Earl, D.C. (1963), Tiberius Gracchus: A Study in Politics, Bruxelles.

El Beheiri, N. (2001), Die Lex Claudia de nave senatorum, RIDA 48, pp. 57-63.

Frank, T. (2004), The Economic History of Rome (second edition revised), Kitchener.

Grziwotz, H. (1985), Der Verfassungverständnis der römischen Republik, Frankfurt Am Main/ New York.

Gundel, H.G. (1979), Claudius no. 1, [in:] Kl. Pauly, vol. 1, col. 1205.

Händl-Sagawe, U. (1995), Der Beginn des 2. Punischen Krieges. Ein historisch-kritischer Kommentar zu Livius Buch 21, München.

Hill, H. (1952), The Roman Middle Class in the Republican Period, Oxford.

Hill, H. (1958), An Unnoticed Roman Allusion in Plautus, Mnemosyne 11, pp. 254-256.

Jenny, B. (1936), Der römische Ritterstand während der Republik, Zürich.

Kienast, D. (1973), Cato der Zensor. Seine Persönlichkeit und seine Zeit, Roma.

Krahmalkov, C.R. (1988), Observations on the Punic Monologues of Hanno in the Poenulus, Orientalia 57, pp. 55-66.

Kunkel, W. (1995), Staatsordnung und Staatspraxis der römischen Republik, München. 
Lippold, A. (1963), Consules. Untersuchungen zur Geschichte des römisches Konsulates von 264 bis 201 v. Chr., Bonn.

Meyer, E. (1975), Römischer Staat und Staatgedanke, Zürich (reed.).

Momigliano, A. (1986), The Rise of the plebs in the Archaic Age of Rome, [in:] K. Raaflaub (ed.), Social Struggles in Archaic Rome, Berkeley-London, pp. 175-197.

Mommsen, Th. (1976), Römische Geschichte, Bd. 2, München (reed.).

Nixon, P. (1924), [trans.], Tittus Maccius Plautus, In five volumes, vol. 3, The Merchant, London.

Oebel, L. (1993), C. Flaminius und die Anfange der römischen Kolonisation im ager Gallicus, Frankfurt am Main.

Pelletier, A. (1969), A propos de lex Claudia de 218 av. J.-C., RELig 35, pp. 7-14.

Scullard, H.H. (1973), Roman Politics 220-150 B.C., Oxford.

Seibert, J. (1993), Hannibal, Darmstadt.

Shatzman, I. (1975), Senatorial Wealth and Roman Politics, Brüssel.

Wildt, H. (1994), Untersuchungen zur Innenpolitik des Gaius Flaminius, München.

Willems, P. (1878), Le sénat de la Republique Romaine, vol. 1, Louvain.

Wolny, M. (2007), Lex Claudia a rozwój politycznej kariery Gajusza Flaminiusza (Lex Claudia and Caius Flaminius' Political Career Development), Studia Prawnoustrojowe 7, pp. 327-334.

Yavetz, Z. (1962), The Policy of C. Flaminius and The Plebiscitium Claudianum, Athenaeum 40, pp. 325-344.

\section{Miron Wolny}

\section{LEX CLAUDIA DE NAVE SENATORUM - POSSIBILITIES OF NEW INTERPRETATIONS}

The Author indicates that the evaluation of the Lex Claudia de nave senatorum issued by Livius was basically dependent on the portrait of Gaius Flaminius, the protector of the provision. The posthumous estimate of G. Flaminius portrait coincided with political contestation that gave it harsher and more radical features, as if indicating a political conflict. However, Livy unarguably sees this dispute via the prism of turbulent historical events of the late republic, namely the bloody political conflicts that were so typical in the times of the Gracchi. Based of his previous research, the Author postulates that a comprehensive review of Plautus' works provides an unconventional source of better recognition of Roman customs reflecting social and economic relations. 